\title{
DEFORMATION HISTORY AND CORRELATION OF PAIKON AND TZENA TERRANES (AXIOS ZONE, CENTRAL MACEDONIA, GREECE)
}

\author{
Katrivanos E. ${ }^{1}$, Kilias A. ${ }^{1}$ and Mountrakis D. ${ }^{1}$ \\ Aristotle University of Thessaloniki, Department of Geology, 54124, Thessaloniki, Greece, \\ ekatriva@geo.auth.gr,kilias@geo.auth.gr,dmountra@geo.auth.gr
}

\begin{abstract}
Paikon and Tzena terranes are situated in the centre part of Axios zone, between Almopia and Paionia ophiolitic belts. Tectonostratigraphic data reveal that both have been affected by the same polyphase deformation and metamorphism, as well that they have the same lithostratigraphic column. The first deformation phase took place during the Middle to Late Jurassic and is associated with ophiolite obduction, nappe - stacking, terrane accretion and crustal thickening $\left(D_{l}\right)$. Metamorphism does not exceed greenschist facies $\left(M_{1}\right)$. Relict HP-LT metamorphic assemblages predating $M_{1}$ metamorphism are possibly developed during subduction processes and overloading of the obducted ophiolites on the continental margin, characterized the initial stages of deformation. Compressional tectonics and intense thrusting with the same kinematics continued in Lower Cretaceous time, affected all pre-Upper Cretaceous units and the obducted ophiolites $\left(D_{2}\right)$. This phase is associated with low-greenschist metamorphism $\left(M_{2}\right)$. The first main extensional event occurs in the Late Cretaceous, related to basin formation and sedimentation $\left(D_{3}\right)$. During Paleocene to Eocene, $D_{4}$ intense imbrication of all tectonic units towards mainly $S W$ takes place again. Nappes collapse and finally crustal exhumation taken place during Oligocene to Miocene, associated with low - angle normal faults, with a main top to the SW sense of movement $\left(D_{5}\right)$. In Miocene to recent times, high - angle normal and strike-slip faults are formed in an extensional to transtensional strain regime $\left(D_{6}\right)$, associated with Neogene to Quaternary basin formation and terrane dispersion. The basement rocks of both terranes are of Pelagonian origin, exhumed as a multiple tectonic window. Keywords: kinematics, tectonic nappe, tectonic window.
\end{abstract}

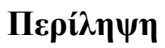

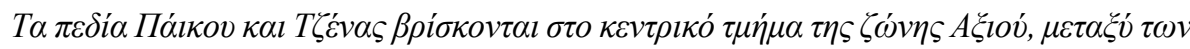

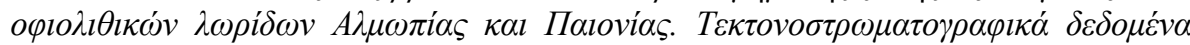

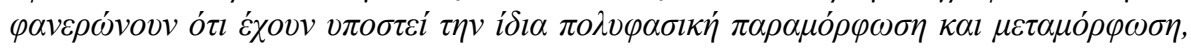

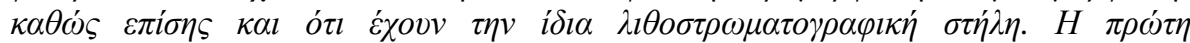

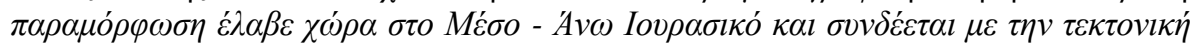

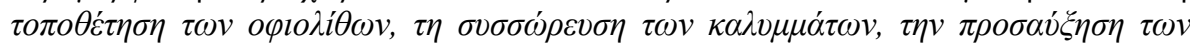

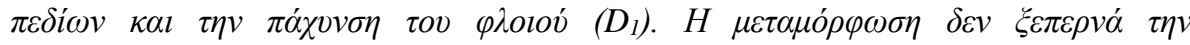

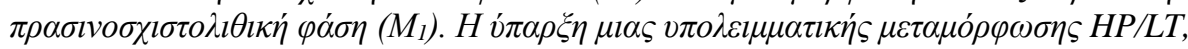

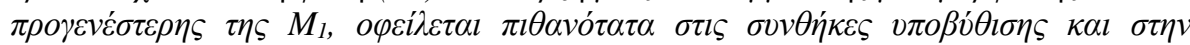

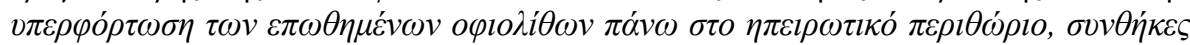

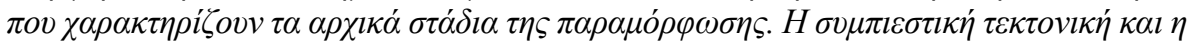




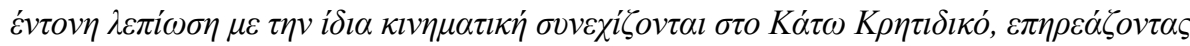

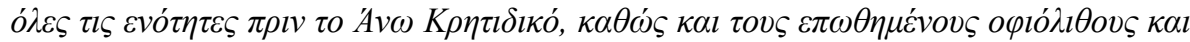

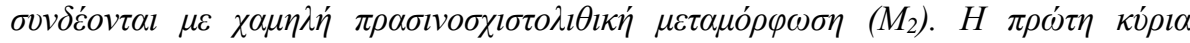

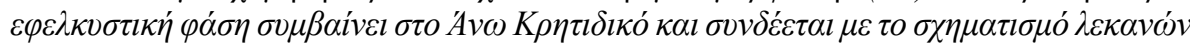

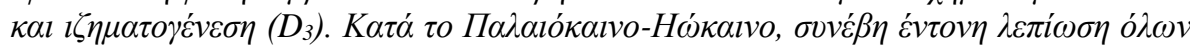

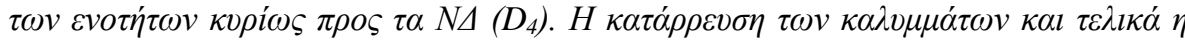

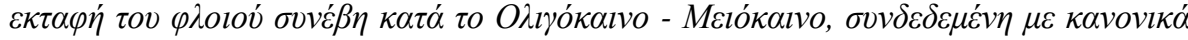

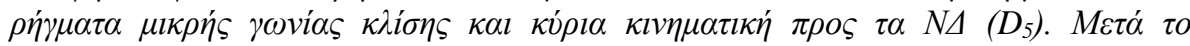

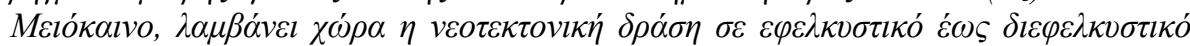

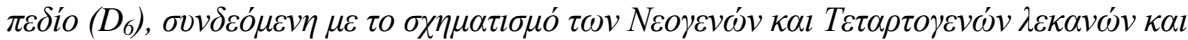
$\tau \eta \delta$

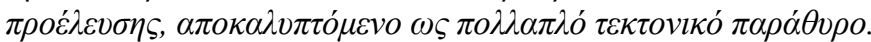

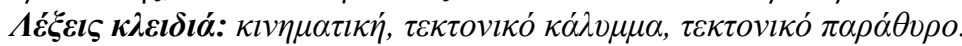

\section{Introduction}

Paikon and Tzena terranes are situated in the centre part of Axios zone, between the Pelagonian nappe and the Serbomacedonian/Rhodope metamorphic province. Axios zone comprises the ophiolite-bearing Almopia Subzone in the West, the Paikon and Tzena terranes (Paikon Subzone) in the Middle, and the also ophiolite-bearing Paionia Subzone in the East (Fig. 1) (Mercier, 1968; Ricou and Godfriaux, 1995; Mercier and Vergely, 2001; Brown and Robertson, 1994, 2003 and Robertson et al., 2013). In terms of the Hellenides classification into tectonostratigraphic terranes H1-H9 as proposed by Papanikolaou (2009, 2013) Paikon and Tzena terranes are considered to belong to H5 continental terrane, while both Almopia Subzone to the west and Paionia Subzone to the east are considered to belong to oceanic terranes (H4 and H6, respectively).

It is clear that the structural evolution and geotectonic position of both Paikon and Tzena terranes have long been a matter of controversy between researchers, with several questions remaining unanswered. Which is the sense of ophiolite obduction and when did this obduction happen? How many ocean basins existed within the Axios zone? Do Paikon and Tzena terranes form a single tectonostratigraphic terrane or they are two discrete terranes with different geological history? Are Paikon and Tzena terranes closely related to the Pelagonian Nappe (or even more to the External Hellenides), or they are of Serbomacedonian/Rhodope nappe stack origin?

The main target of this work is to study the geological structure and the relation of Paikon and Tzena terranes, as well as to reconstruct the evolution of deformation from Jurassic till recent times. We carried out geological mapping and detailed structural investigations, as well as thorough study of geological contacts, combined with all available geochronological and stratigraphic data. Shear criteria such as S-C fabrics, shear bands, asymmetric boudins as well as $\sigma$ - and $\delta$ - clasts, were used in order to study the geometry and the kinematics of deformation (Hanmer and Passchier, 1991 and Passchier and Trouw, 2005).

\section{Description of tectonostratigraphic units}

\subsection{Paikon terrane}

Paikon terrane consists mainly of the units given below, described from the top to the bottom of the tectonostratigraphic column (Fig. 2, 3) (Mercier, 1968; Mavrides et al., 1982; Mercier and Vergely, 1984; Godfriaux and Ricou, 1991; Bonneaux et al., 1994; Ferriere et al.,. 2001; Brown and Robertson, 2003 and Katrivanos et al., 2013).

\subsubsection{Ophiolites}

At the western margin of this terrane, the Almopia ophiolites rest along tectonic contacts on the Maestrichtian Tchouka flysch and in places directly on the Upper Cretaceous Theodoraki carbonates. 
Serpentinites, dolerites and basic lavas form an ophiolitic sequence of Triassic - Jurassic age. At the eastern margin, the Guevgeli/Paionia Ophiolites rest tectonically on the Upper Jurassic to Lower Cretaceous Griva-Khromni carbonates. Near the contact, gabbros dominate, while progressively towards the east the upper levels of an ophiolitic sequence crop out, i.e. sheeted dike complex and pillow-lavas of Jurassic age. Into this series, the Fanos Granite intruded during the Late Jurassic, 160 Ma (Soldatos et al., 1993 and Anders et al., 2005). In both Almopia and Paionia ophiolitic sequences, red, deep-sea sediments are deformed together with the ophiolitic rocks.

\subsubsection{Tchouka Flysch}

Sandstones alternating with siltstones, calcarenites and schists, form a typical flysch series, where carbonate olistoliths often appear. Tchouka Flysch was strongly deformed under brittle conditions and formed tectonic slices. Hence, the flysch rocks alternate tectonically with the underlying carbonate rocks. Tchouka Flysch is considered to be Maestrichtian in age.

\subsubsection{Theodoraki Carbonates}

It comprises mainly carbonate rocks deposited unconformably upon the lower units, beginning with the Cenomanian transgression. The series starts with dolomites, followed by neritic limestones and intercalations of limestones with sandstones and carbonate conglomerates. In the upper part, pelagic limestones dominate and the rocks show a deepening of the basin, until the deposition of Tchouka flysch. Their age is Late Cretaceous (Cenomanian to Maestrichtian).

\subsubsection{Grammos Metaflysch}

Metasandstones alternates with metapelites, metaconglomerates and a few limestones. The red sandstone bed intercalated with clastic material of volcanic origin characterizes the series. Grammos Metaflysch is considered of Early Cretaceous age (post-Kimmeridgian and pre-Albian).

\subsubsection{Griva-Khromni Carbonates}

It consists mainly of recrystallized carbonate rocks, dolomitic in places, intercalated with phyllites and calcareous, as well as sericite schists. Grey marbles dominate in the lower levels of this series. This unit is considered to be of Late Jurassic to Early Cretaceous age.

\subsubsection{Kastaneri-Khromni Volcanosedimentary (VS) Series}

It consists mainly of acidic volcanic rocks (fine grained tuffs, ignimbrites, sericite and quartz porphyry and metarhyolites), intercalated with clastic sediments (metaarkoses, metaconglomerates, pyroclastic sandstones) and with lenses/horizons or olistolithes of recrystallized limestones. In the western part of Paikon Mt., this volcano-sedimentary series contains both volcanic rocks of acidic to intermediate composition (keratophyres), and of basic composition (spilites and diabases). The age of this series is considered to be Middle to Late Jurassic.

\subsubsection{Gkola Tchouka-Gropi Carbonates}

This unit is formed mainly of white to grey calcitic and dolomitic marbles and calc schists. The carbonate rocks are strongly mylonitized, especially near the contact with the tectonically overlying volcano-sedimentary formation of Kastaneri-Khromni. The mineral paragenesis comprises calcite, quartz, white mica, sericite and chlorite. White mica is sericitized and calcite dynamically recrystallized. The age of this series should be Late Jurassic to Early Cretaceous. 


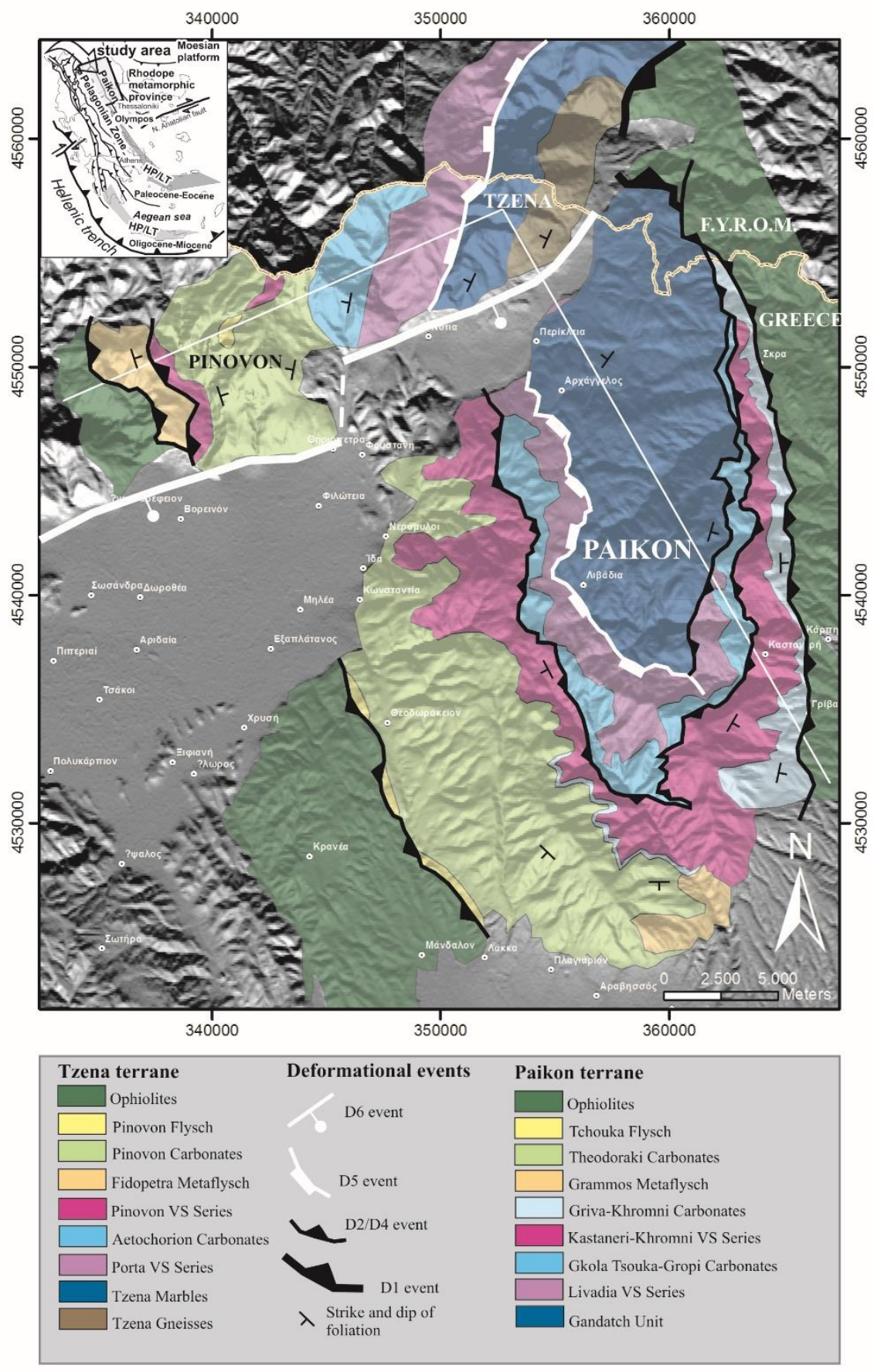

Figure 1- Geological map of Paikon and Tzena terranes (modified from Federal Geological Institute of Serj, 1970; Mavrides et al., 1982; Mercier and Vergely, 1984; Godfriaux and Ricou, 1991; Brown and Robertson, 2003; Galeos et al., 2003; Katrivanos et al., 2001, 2013). (Co-ordinates system: Greek metric grid). Inset: Geological units of Hellenides with the position of the study area (square). 


\subsubsection{Livadia VS Series}

This volcano-sedimentary series of Middle to Upper Jurassic age consists of chlorite-sericite schists, recrystallized limestones, quartz schists, and calcareous schists, intercalated with volcanic rocks: tuffs, metarhyolites, sericitised porphyry and metabasic rocks. Baroz et al. (1987) describe also for the Livadia Formation medium- to high-Si phengite.

\subsubsection{Gandatch Unit}

It is composed of intercalations of calcareous, chlorite, sericite and epidotic phyllites and schists with white or dark marbles and finely laminated marbles (Fig. 2, 3). White or grey, mostly thickbedded marbles and locally dolomitic marbles exhumed as the deepest rocks in the core of the Gandatch Unit. The Gandatch Unit is not directly dated, as no determinable fossils have been found because of strong recrystallization. It is considered as Triassic to Early-Middle Jurassic age. Medium to high-Si phengite, chlorite and Na-amphibole were recognized by Baroz et al. (1987) in schists of the formation.

SW NE NW

SE

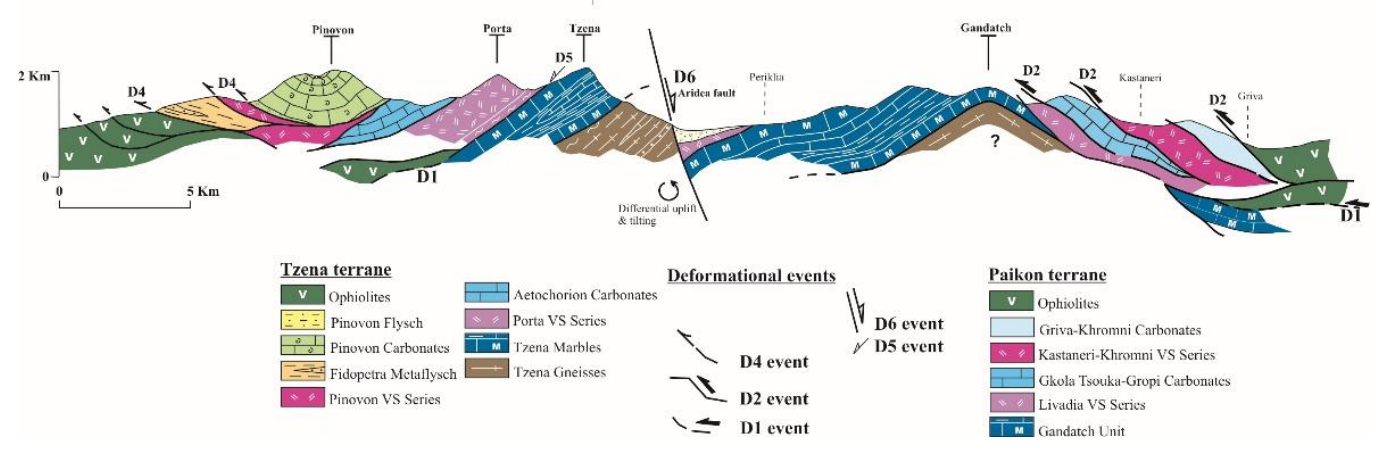

Figure 2 - Schematic geological cross - section, illustrating the geometry of deformation and the geological structure of Paikon and Tzena terranes.

\subsection{Tzena terrane}

Tzena terrane comprised mainly from the units given below (Quaternary volcanics, i.e. andesitic lavas and tuffs, are not described here but shown only on the map), described from the top to the bottom of the tectonostratigraphic column (Fig. 2, 3) (Mercier, 1968; Migiros and Galeos, 1990; Katrivanos et al., 2001 and Galeos et al., 2003).

\subsubsection{Ophiolites}

West of Pinovon Mt., Garefi ophiolites form a tectonic pile of ultrabasic thrust sheets, consisting of serpentinized dunites and hartzburgite tectonites. Diabase veins occur only locally. The age of this unit is considered to be as Jurassic. We consider this ophiolitic sequence as similar to Almopia ophiolites in Paikon column.

\subsubsection{Pinovon Flysch}

Pinovon nappe consists mainly of transgressive limestones that carry over a flysch series. Phyllites and sandstones intercalations, together with schists and siltstones constitute this typical flysch of Maestrichtian age. This flysch is analogous to Tchouka Flysch in Paikon tectonostratigraphic column.

\subsubsection{Pinovon Carbonates}

The transgressive limestones of Pinovon nappe consist mainly of alternations of dolomites and limestones. White crystalline neritic limestones become dark grey pelagic limestones to the upper levels of this series, which is analogous to Theodoraki carbonates in Paikon column and considered to be of Late Cretaceous age. 


\subsubsection{Fidopetra Metaflysch}

This series is located to the west of Pinovon Mountain, below Pinovon syncline nappe and consists mainly of calcareous phyllites and metasandstones, with intercalations of limestones, conglomerates, shales and schists. It is analogous to Upper Albian Grammos Metaflysch in Paikon column.

\subsubsection{Pinovon VS Series}

It is a sequence of mainly volcanic rocks, such as spilites, metaandesites and keratophyres, together with a few pyroclastic and carbonate rocks. This unit is analogous to Kastaneri-Khromni VS series in Paikon column and its age is Upper Jurassic.

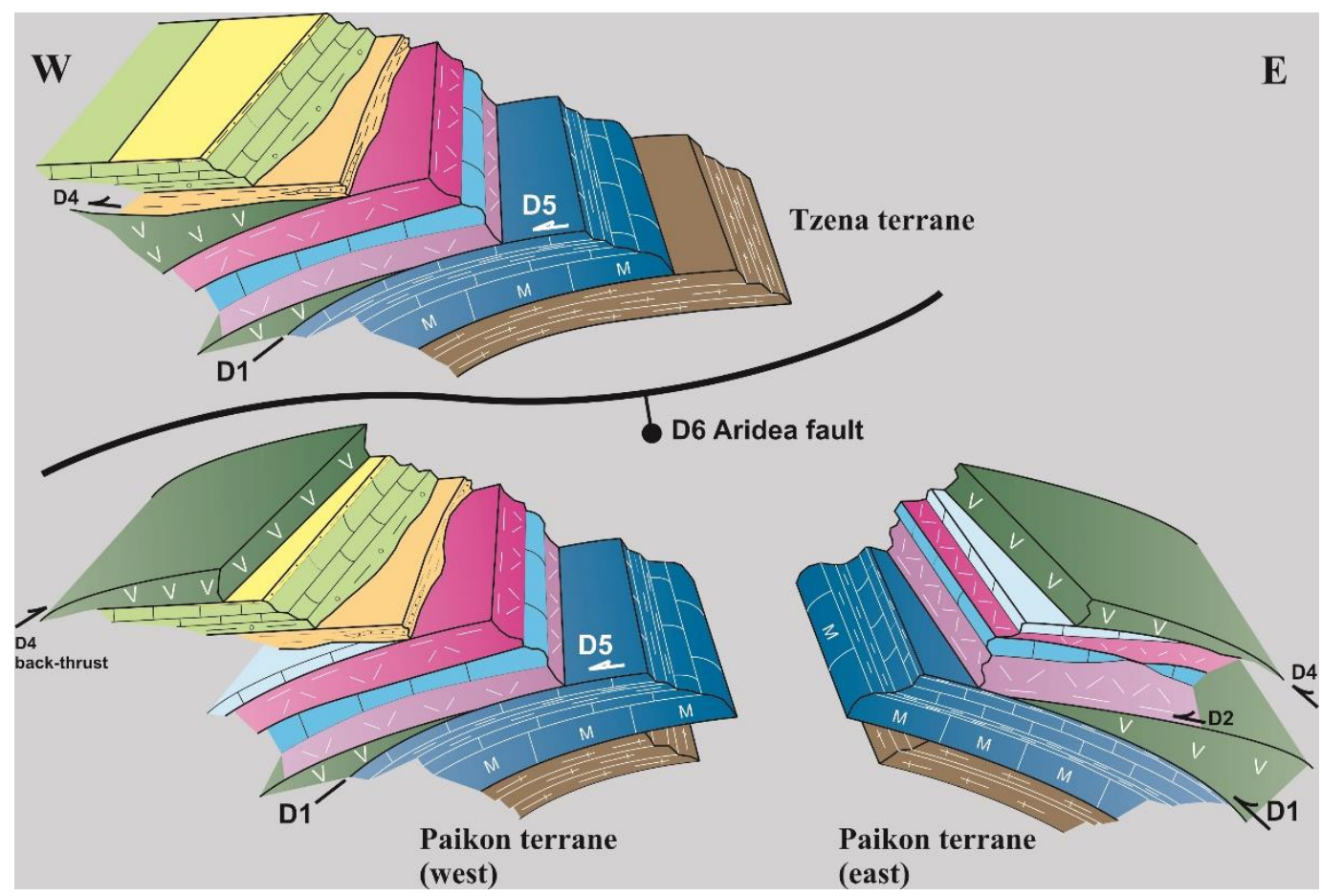

Figure 3 - 3-D tectonostratigraphic blocks of Paikon and Tzena terranes (symbols and colors as in Fig. 1, 2).

\subsubsection{Aetochorion Carbonates}

It consists of crystalline limestones and cipolins, alternated with chloritic schists and phyllites. This series is analogous to the other Upper Jurassic-Lower Cretaceous carbonate rocks in Paikon column.

\subsubsection{Porta VS Series}

Acid mylonitised metarhyolites alternates with basic porphyroids and prasinites, with few marbles, greenschists and quartzites that complete the series. Black-coloured chloritic-calcitic schists and phyllites are developed as a thin layer in the base of Porta VS Series. The whole is metamorphosed in greenschist facies, while the age of this unit is Middle to Upper Jurassic. Porta VS Series is analogous to Livadia VS Series of Paikon tectonostratigraphic column.

\subsubsection{Tzena Marbles}

It consists of white, thick-bedded marbles, intercalated with calc schists and cipolinic marbles. This unit is analogous to Gandatch Unit of Paikon column, considered to be as Triassic age. 


\subsubsection{Tzena Gneisses}

A composite unit consisted of albitic and chloritic gneisses, cipolines, amphibolites and piemontitic schists. The age of this unit is considered to be as Paleozoic - Lower Triassic. This unit is not exposed to Paikon terrane, which forms the hangingwall part of Aridea fault, supposed to be buried beneath Gandatch unit.

\section{Deformation History}

Both Paikon as well as Tzena tectonostratigraphic terranes that described above have undergone the same polyphase deformation and metamorphism $\left(D_{1}-D_{6}\right)$, from Mid-Jurassic to recent times. Shortening alternated with extension and the deformation conditions evolved from ductile to brittle. Compressional events are related to nappe stacking, terrane accretion and crustal thickening, while extensional ones are related to orogenic collapse, terrane dispersion, isostatic rebound, unroofing and crustal thinning (Kilias et al., 2010 and Katrivanos et al., 2013).

\section{1. $D_{1}$ event}

The structures of the first deformational event $\left(D_{1}\right)$ are penetrative and affect clearly the lower units of Triassic age, as well as the Mid- to Late Jurassic volcano-sedimentary series.

A penetrative synmetamorphic foliation $\left(S_{1}\right)$ is parallel to the axial planes of well-preserved isoclinal folds $\left(F_{1}\right)$ that deform a pre-existing $S_{0}$ foliation. Usually, fold axes are parallel to sub-parallel to an E-W to NE-SW trending, mineral stretching lineation $\left(\mathrm{L}_{1}\right)$. No clear kinematic indicators have been preserved due to the strong overprinting by subsequent tectonics. Elongated grains and aggregates of quartz, white mica, chlorite and rarely aktinolite or biotite mainly define the mineral stretching lineation $\left(\mathrm{L}_{1}\right)$. According to syn- $\mathrm{D}_{1}$ mineral assemblages, metamorphic conditions did not exceed the greenschist facies $\left(\mathrm{M}_{1}\right)$. Baroz et al. (1987) suggest that metamorphic conditions range from the lawsonite-chlorite-albite-facies through transitional $\mathrm{Na}$-amphibole-greenschist facies to the chlorite sub-zone of the greenschist facies.

In this study, we assume that $\mathrm{D}_{1}$ is of Late Jurassic age and responsible for the strong synmetamorphic deformation and internal imbrication of the Triassic basement units and the MidLate Jurassic volcano-sedimentary series (Fig. 2, 3).

A high pressure metamorphism (HP-LT) of Mid- to Late Jurassic age is also suspected by Baroz et al. (1987), related to a subduction zone, i.e. a subduction during the closure of the Axios Ocean (=Neotethys) and the Late Jurassic plate convergence, or to a tectonic overpressure caused by thrusting. In any case, this HP-LT metamorphism $\left(\mathrm{M}_{0}\right)$ predates $\mathrm{M}_{1}$ metamorphism, because the syn- $S_{1}$ mineral assemblages are always related to greenschist facies metamorphic conditions and the HP/LT minerals occur only as remnants. Parts of the lower Paikon units (Gandatch and volcanosedimentary units) were detached and buried in a depth of at least $20 \mathrm{~km}$ beneath an emplacing part of oceanic lithosphere in response to continental margin-trench collision and collision of the Paikon continental margin with the oceanic lithosphere of the Axios Ocean. Most et al. (2001) and Kilias et al. (2010) in the eastern margin of the Pelagonian nappe described similar geotectonic conditions. During $\mathrm{D}_{1}$ the HP/LT metamorphic rocks, came back to shallower crustal levels and were strongly deformed and imbricated. Unroofing of the metamorphic rocks formed during $\mathrm{D}_{1}$ took place prior to or during the early stages of the accumulation of the overlying Late Jurassic-Early Cretaceous shallow water sediments.

\section{2. $D_{2}$ event}

$D_{1}$ structures are strongly overprinted by a later, deformational event $D_{2}$, recognized in the Triassic units, the volcano-sedimentary series and the Late Jurassic - Early Cretaceous sedimentary units.

Asymmetric, recumbent to overturned, tight to isoclinal folds $\left(\mathrm{F}_{2}\right)$ refold both the $\mathrm{S}_{1}$ foliation, as well as the isoclinal $F_{1}$ folds. A new foliation $S_{2}$ is parallel to $F_{2}$ axial planes. $F_{1}$ and $F_{2}$ folds axes 
are mostly parallel, although in some places a scattering of $\mathrm{F}_{2}$ folds from NW-SE to NE-SW is observed. $S_{1}$ is usually rotated into parallelism with the $S_{2}$ foliation, so that in some places only one foliation is recognized. $\mathrm{D}_{2}$ is associated with an E-W to NE-SW $\left(210^{\circ}-260^{\circ}\right)$ trending mineral stretching lineation $\left(\mathrm{L}_{2}\right)$, defined mainly by $\mathrm{M}_{2}$ sericite and chlorite, as well as quartz aggregates. $\mathrm{L}_{2}$ is developed parallel to $\mathrm{F}_{2}$ fold axes. The sense of shear during $\left(\mathrm{D}_{2}\right)$ is top-to-the-WSW. Opposite sense of movement is observed in some cases, showing the existence of an important coaxial component of deformation during $\mathrm{D}_{2}$.

Metamorphic conditions lie in the lower greenschist facies $\left(\mathrm{M}_{2}\right)$. Replacement of biotite by chlorite and of green amphibole by actinolite, as well as fine grained sericitisation of white mica, taken place during $\mathrm{M}_{2}$.

During $\mathrm{D}_{2}$ in the Early Cretaceous, W- to SW-vergent imbrication and folding took place again, now affecting the Upper Jurassic - Lower Cretaceous sedimentary series, the Jurassic volcano-sedimentary series, the Triassic ones, as well as the ophiolitic bodies. The ophiolites continued to advance westwards during that time, overthrusting the Upper Jurassic-Lower Cretaceous sediments (Fig. 2, 3).

\section{3. $D_{3}$ event}

Structures of $D_{3}$ event are discrete, narrow mylonitic shear zones related to a mylonitic foliation $\left(S_{3}\right)$ and a SW-NE to SSW-NNE trending mineral stretching lineation $\left(\mathrm{L}_{3}\right)$. The main sense of shear is top to the SW to SSW $\left(200^{\circ}-210^{\circ}\right)$. Rarely, kinematic indicators reveal the opposite sense towards NE. $D_{3}$ structures show a relatively constant geometry and affect the penetrative $D_{1}$ and $D_{2}$ structures. Dynamic recrystallization of quartz, as well as sericitisation of white mica takes place along the $\mathrm{D}_{3}$ shear zones, which show mostly a down-dip sense of movement, possibly indicating an extensional tectonic regime during $\mathrm{D}_{3}$.

$\mathrm{D}_{3}$ event must be Late Cretaceous (Early Cenomanian) because it overprints clearly $\mathrm{D}_{2}$ structures but does not affect the trangressive Upper Cretaceous carbonate sediments and flysch. Sharp and Robertson (1993) and Kilias et al. (2010) also describe a possible extensional event of Late Cretaceous age (Cenomanian-Turonian), related to basin subsidence and crustal unroofing, analogous to $\mathrm{D}_{3}$ event.

Upper Cretaceous extension ( $\mathrm{D}_{3}$ event) and exhumation of deeper crustal rocks is associated with basin subsidence and deposition of the Upper Cretaceous limestones and flysch (Cenomanian to Maastrichtian), outcropping on the western flanks of Paikon and Pinovon mountains (Fig. 2, 3).

\section{4. $\mathrm{D}_{4}$ event}

Structures of $\mathrm{D}_{4}$ event are open to tight kink folds $\left(\mathrm{F}_{4}\right)$ associated with reverse faults, affecting all units, including the transgressive Upper Cretaceous limestones and flysch, as well as the ophiolites. $\mathrm{D}_{4}$ contractional structures show a general vergence towards SW. An $\mathrm{S}_{4}$ crenulation cleavage parallel to axial planes of $\mathrm{D}_{4}$ folds without visible recrystallization is usually developed.

Thus, $\mathrm{D}_{4}$ structures form a well developed, NW-SE trending fold and thrust belt, active from Paleocene to Eocene and resulting in renewed SW-directed imbrication of all units. In the western Paikon, Almopias ophiolites overthrust the Theodoraki Carbonate Formation and Tchouka flysch, along a NEward $\mathrm{D}_{4}$ back-thrust (Fig. 1, 3; Mercier and Vergely, 2001; Brown and Robertson, 2003).

\section{5. $D_{5}$ event}

$\mathrm{D}_{5}$ structures are large, low-angle, dip-slip to oblique normal faults, considered of Oligocene Miocene age (Fig. 1,2). They are brittle structures, mainly NW-SE striking, with a main sense of movement towards SW in the western and towards NE in the eastern flanks of Paikon and Tzena terranes. They clearly overprint all previously described structures including the Paleocene-Eocene fold and thrust belt. Some of the tectonic contacts in the eastern Paikon Massif are reworked by the extensional $\mathrm{D}_{5}$ low angle faults, juxtaposing structurally higher against lower formations, through 
omission of several intermediate formations (e.g. Griva-Khromni limestones are tectonically overlying directly the Gandatch unit).

The final exhumation of Paikon and Tzena tectonostratigraphic units, as well as crustal thinning occurred during the Oligocene-Miocene extensional event $\mathrm{D}_{5}$ under brittle conditions. Simultaneously, unroofing and exhumation of the External Hellenides units, took place under ductile conditions at deeper structural levels of the Hellenic orogen (Kilias, 1995).

\section{6. $D_{6}$ event}

Transtension tectonics characterizes the $\mathrm{D}_{6}$ event. During Miocene-Pliocene, faulting overprinted all previously described structures. $\mathrm{D}_{6}$ structures include high-angle normal, dip-slip to oblique faults, as well as strike-slip faults. A very important $\mathrm{D}_{6}$ fault is the ENE-WSW striking and SSEdipping Aridea fault zone, which is considered to be originally a dextral strike-slip fault, reactivated during the Pliocene-Quaternary until recent as a normal dip-slip fault (Pavlides et al., 1990). In the study area, this fault separates Tzena from Paikon terrane, due to differential uplift and tilting of the footwall Tzena terrane (Katrivanos et al., 2001), forming the Neogene to Quaternary Notia-Periklia depression and leading to terrane dispersion (Fig. 1,2). The omission of Paleozoic basement in the Paikon terrane, described above for the Tzena terrane, can be ascribed to this $\mathrm{D}_{6}$ normal fault.

\section{Discussion and Conclusion}

Paikon and Tzena terranes constitute a complex tectonic nappe pile with several tectonostratigraphic units, including the obducted Neotethyan ophiolites, far-traveled westwards from their initial place (Fig. 3). According to their tectonostratigraphy and structural evolution, as presented here in detail, we suggest that Paikon and Tzena terranes form two identical tectonostratigraphic terranes, on the contrary to other previous approaches (Godfriaux and Ricou, 1991 and Ricou and Godfriaux, 1991, 1995).

Nappe stacking and deformation started during the Mid- to Upper Jurassic. The primary emplacement of ophiolites on the Triassic marbles was possibly associated with the overthrusting of the volcanoclastic series. Brown and Robertson (2003) assumed Jurassic, northeastward subduction that created an island arc within the Paikon Massif, coupled with back-arc rifting, generating the Guevgeli Ophiolites and related units behind the Paikon arc. They also propose that overthrusting of the Paionias Ophiolites on the Paikon Massif took place firstly during the Late Cretaceous to Early Tertiary.

Nevertheless, in both Paikon and Tzena terranes, feeds dykes of the overlying volcanic formations are not found inside the lower units. Therefore, we suggest that these volcanic rocks of calc-alcaline composition formed somewhere else, during an initial Jurassic intra-oceanic subduction in the Neotethys Ocean, as also assumed by Michard et al. (1998), Katrivanos et al. (2013) and Michail et al. (2014). Furthermore, Jurassic magmatic series (Chortiatis series; Mussalam, 1991) including reefal limestones of Late Jurassic age (Kimmeridgian-Tithonian) and clastic deposits with spilite, keratophyre, andesite and granodiorite elements (Mussalam, 1991 and Michard et al., 1998), exposed along the western margin of the Serbomacedonian massif, can be correlated in lithology and age with the Paikon volcano-sedimentary formations. This Chortiatis magmatic series and the volcanoclastic series along the western Serbo-Macedonian margin was interpreted by Michard et al. (1998) as having developed in an intra-oceanic island arc setting related to an intra-oceanic subduction predating the obduction of the Axios (=Neotethyan) ophiolites. Such a tectonic setting and place may be assumed also for the Paikon and Tzena volcano-sedimentary units, prior their westwards emplacement onto the Triassic units, owing to the arc-continent collision.

Therefore, we suggest that ophiolites obduction upon the continental series of Paikon and Tzena terranes took place simultaneously with the ophiolite tectonic emplacement towards west upon the Triassic marbles of the eastern Pelagonian margin, described by several researches (Vergely, 1984; Brown and Robertson, 2003, 2004; Kilias et al., 2010 and Katrivanos et al., 2013). 
Finally, the nappe pile evolved into a multiple tectonic window, where the lower units emerged under the Jurassic volcano-sedimentary series and the Upper Jurassic-Lower Cretaceous carbonate series and these again under the duplicated, ophiolitic nappe (Fig. 3). The tectonic window formed due to successive compressional and extensional events from Jurassic to Tertiary time. The final configuration of the tectonic window resulted from the Oligocene-Miocene extension $\left(\mathrm{D}_{5}\right)$. Considering that Paikon and Tzena terranes are identical, the lower units of both terranes, as it is assumed for the Paikon lower units by Katrivanos et al. (2013), are possibly of Pelagonian origin (i.e. the eastward prolongation of $\mathrm{H} 3$ terrane, according to Hellenides terrane classification given by Papanikolaou, 2009, 2013).

Godfriaux and Ricou (1991), Ricou and Godfriaux (1991, 1995) proposed also an overall westward overthrusting of Paikon units but of Tertiary age. In their approach, the Paikon Massif is considered as a multiple tectonic window of Tertiary age beneath the thrusted slices of the Axios Zone ophiolites and the Pelagonian Nappe of metamorphic rocks. Additionally, Tzena Massif is considered as a Tertiary metamorphic nappe with an origin from the east (Rhodopic hinterland), that was placed tectonically upon both the ophiolites and the Paikon units. The lower unit of the Paikon Massif is correlated with the carbonate unit of Olympos-Ossa, while the overthrusted volcanic rocks with the Ambelakia HP/LT unit. However, we do not share this view, because those two windows show a different structural evolution and tectonic position. The Olympos-Ossa window represents a deeper tectonic unit of Hellenides belonging to the External Hellenides below the Pelagonian nappe pile, exhumed first during the Tertiary.

In conclusion, we suggest:

- Both Paikon and Tzena tectonostratigraphic terranes were affected by six main Alpine deformational events. They started in Mid-Late Jurassic time with an intra-oceanic subduction in the Axios Ocean (=Neotethys) and continued progressively until today. Shortening alternated with extension and the deformation conditions evolved from ductile to brittle. Compressional events are related to ophiolite obduction, nappe stacking, terrane accretion and crustal thickening, while extensional ones are related to orogenic collapse, unroofing, terrane dispersion and crustal thinning.

- Paikon and Tzena terranes are tectonostratigraphically identical and each one of them is a composite terrane that formed by terrane accretion, i.e. a complicated tectonic nappe pile, including obducted ophiolites rooted in the Axios zone (=Neotethys), far-travelled westward from their initial place.

- The core of both terranes, i.e. gneisses and marbles, may be of Pelagonian origin, exhumed as a multiple tectonic window under the overthrusted nappe pile.

- The two composite terranes are separated during $\mathrm{D}_{6}$ event, along Arideas fault, which is responsible for terrane dispersion and related to Neogene-Quaternary basin formation.

\section{Acknowledgments}

We would like to thank Prof. D. Papanikolaou for his constructive comments and suggestions during reviewing.

\section{References}

Anders, B., Reischmann, T., Poller, U. and Kostopoulos D., 2005. Age and origin of granitic rocks of the eastern Vardar Zone, Greece: New constrains on the evolution of the Internal Hellenides, Journal Geol. Society London, spec. Issue, 162, 857-870.

Baroz, F., Bebien, J. and Ikenne, M., 1987. An example of HP-LT metamorfic rocks from an islandarc: the Paikon series (Innermost Hellenides, Greece), Journal of Metamorphic Geology, 5, 509-527. 
Bonneau, M., Godfriaux, I., Moulas, Y., Fourcade, E. and Masse, J., 1994. Stratigraphie et structure de la bordure orientale de la double fenetre du Paikon (Macedoine, Grece), Bulletin Geological Society of Greece, 30/1, 105-114.

Brown, S. and Robertson, A., 1994. New structural evidence from the Mesozoic-early Tertiary Paicon unit, Northern Greece, Bulletin Geological Society of Greece, 30/1, 159-170.

Brown, S. and Robertson, A., 2003. Sedimentary geology as a key to understanding the tectonic evolution of the Mesozoic-Early Tertiary Paikon Massif, Vardar suture zone, N. Greece, Sedimentary Geology, 160, 179-212.

Brown, S.A.M. and Robertson, A.H.F., 2004. Evidence for the Neotethys ocean rooted in the Vardar zone: evidence from the Voras Mountains, NW Greece, Tectonophysics, 381, 143-173.

Federal Geological Institute of Serj, 1970. Geological map 1:500.000, Military Geographical Institute, Belgrade.

Ferriere, J., Bonneau, M., Caridroit, M., Bellier, J.P., Gorican, S. and Kollmann, H., 2001. Les nappes tertiaires du Paikon (zone de Vardar, Macédoine, Grèce): arguments stratigraphique pour une nouvelle interprétation structurale, C. R. Acad. Sci. Paris, 332, 695-702.

Galeos, A., Karfakis, J. and Photiades, A., 2003. Geological map of Greece, 1:50000, Promahi sheet, Institute of Geology and Mineral Exploration, Athens.

Godfriaux, I. and Ricou, L.E., 1991. Le Paicon, une fenetre tectonique dans les Hellenides Internes (Macedoine, Grece), C. R. Acad. Sci. Paris, 313/2, 1479-1484.

Hanmer, S. and Passchier, C.W., 1991. Shear - Sense Indicators: A Review, Geological Survey of Canada, 17, 72-90.

Katrivanos, E., Mountrakis, D., Kilias, A. and Pavlides, S., 2001. Preliminary results of the geological structure and kinematics of deformation in Tzena Mt. (Paikon Subzone, Central Macedonia, Greece), Bulletin Geological Society of Greece, 34/1, 137-147 (in Greek).

Katrivanos, E., Kilias, A. and Mountrakis, D., 2013. Kinematics of deformation and structural evolution of the Paikon Massif (Central Macedonia, Greece): A Pelagonian tectonic window? N. Jb. Geol. Palaeont. Abh., 269/2, 149-171.

Kilias, A., 1995. Tectonic evolution of the Olympus-Ossa Mt.: Emplacement of the blueschists unit in eastern Thessaly and exhumation of Olympus-Ossa carbonate dome as a result of tertiary extension (Central greece), Mineral Wealth, 96, 20-42.

Kilias, A., Frisch, W., Avgerinas, A., Dunkl, I., Falalakis, G. and Gawlick, H.J., 2010. Alpine architecture and kinematics of deformation of the northern Pelagonian nappe pile in the Hellenides, Austrian Journal of Earth Sciences, 103/1, 4-28.

Mavrides, A., Matarangas, D. and Karfakis, J., 1982. Geological map of Greece, 1:50000, Skra sheet, Institute of Geology and Mineral Exploration, Athens.

Mercier, J., 1968. Etude geologique des zones Internes des Hellenides en Macedoine centralle. Contribution a l' etude du metamorphisme et de l' evolution magmatique des zones internes des Hellenides, Annales Geologique Pays Hellenic, 20, 1-739.

Mercier, J., Vergely, P. and Bebien, J., 1975. Les ophiolites helleniques “obductees" au Jurassique superieur sont-elles les vestiges d' un ocean tethysien ou d' une mer marginale perieuropeene? C.R. somm. Soc. Geol. France, 4, 108-112.

Mercier, J. and Vergely, P., 1984. Geological map of Greece, 1:50.000, Edhessa sheet, Institute of Geology and Mineral Exploration, Athens.

Mercier, J. and Vergely, P., 2001. The Paikon Massif revisited comments on the Late CretaceousPaleogene geodynamics of the Axios-Vardar zone. How many Jurassic ophiolitic basins? (Hellenides, Macedonia, Greece), Bulletin Geological Society of Greece, 34/6, 2099-2112.

Michail, M., Kilias, A., Koroneos, A., Ntaflos, T. and Pipera, K., 2014. Tectonic structure and emplacement of the Fanos Granite in the Axios Zone (Macedonia, N. Greece), XX, CBGA, Bul. Shk. Gjeol., 1, 129-132, Tirana.

Michard, A., Feinberg, H. and Montigny, R., 1998. Supra-ophiolite formation from the Thessaloniki mappes (Greece) and associated magmatism: an intra-oceanic subduction predating the Vardar obduction, C. R. Acad. Sciences, Paris, 327, 493-499. 
Migiros, G. and Galeos, A., 1990. Tectonic and stratigraphic significance of the Ano Garefi ophiolitic rocks, Northern Greece. In: Melpas, J.E., Moores, E., Panayiotou A. and Xenophontos, E., eds., Ophiolites: Oceanic Crustal Analogues, Proceedings Symposium, Troodos 1987, Geological Survey Department, Nicosia, 279-284.

Most, T., Frisch, W., Dunkl, I., Kadosa, B., Avgerinas, A. and Kilias, A., 2001. Geochronological and structural investigation of the Northern Pelagonian crystalline zone. Constraints from $\mathrm{K} / \mathrm{Ar}$ and zircon and apatite fission track dating, Bulletin of Geological Society of Greece, 34, 91-95.

Mussalam, K., 1991. Geology, geochemistry and the evolution of an oceanic crustal rift at Sithonia. NE Greece. In: Peters, T., Nikolas, A. and Coleman, R.G., eds., Ophiolite Genesis and the Evolution of the Oceanic Lithosphere, Kluver Academic Publishing, London, 685-704.

Papanikolaou, D., 2009. Timing of tectonic emplacement of the ophiolites and terrane paleogeography in the Hellenides, Lithos, 108, 262-280.

Papanikolaou, D., 2013. Tectonostratigraphic models of the Alpine terranes and subduction history of the Hellenides, Tectonophysics, 595-596, 1-24.

Passchier, C.W. and Trouw, R.A.J., 2005. Microtectonics. Springer-Verlag, $2^{\text {nd }}$ edition, 366 pp.

Pavlides, S., Mountrakis, D., Kilias, A. and Tranos, M., 1990. The role of strikeslip movements in the extensional area of the northern Aegean (Greece), Annale Tectonique, 4, 196-211.

Ricou, L.E. and Godfriaux, I., 1991. Une coupe a travers les ophiolites et gneiss allocthones entre le massif Pelagonien et la fenetre du Paikon (Grece du Nord), C. R. Acad. Sci. Paris, 313/ 2, 1595-1601.

Ricou, L.E. and Godfriaux, I., 1995. Mise au point sur la fenetre multiple du Paicon et la structure du Vardar en Grece, C. R. Acad. Sci. Paris, 321/2, 601-608.

Robertson, A.H.F., Trivic, B., Deric, N. and Bucur, I.I., 2013. Tectonic development of the Vardar ocean and its margins: Evidence from the Republic of Macedonia and Greek Macedonia, Tectonophysics, 595-596, 25-54.

Sharp, I.R. and Robertson, A.H.F., 1993. Evidence for Turonian rift related extensional subsidence and eastward Early Tertiary thrusting western Paikon Zone, Northern Greece, Bulletin Geological Society Greece, 28, 99-110.

Soldatos, T., Koroneos, A. and Christophides, G., 1993. Origin and evolution of the Fanos granite (Macedonia, northern Greece): trace and REE modeling constrains. In: Konispoliatis, N., ed., Special Vol. in honor of Prof. G. Panagos, Univ. Athens Scientific Publications, B, 789-812.

Vergely, P., 1984. Tectoniques des ophiolites dans les Hellenides Internes deformation, metamorphisms et phenomenes sedimentaires. Consequences sur l' evolution des regions Tethysiennes Occidentales, PhD Thesis, Universite de Paris - Sud, Orsay, 1-560. 